DOI: 10.19112/2413-6174-2021-S1-18

\title{
ПРОФИЛЬ АНТИБИОТИКОРЕЗИСТЕНТНОСТИ МИКРОФЛОРЫ КИШЕЧНИКА ЦЫПЛЯТ-БРОЙЛЕРОВ ПРИ ИСПОЛЬЗОВАНИИ НАНОЧАСТИЦ МЕТАЛЛОВ В КОРМЛЕНИИ
}

\author{
И.Ф. Каримов*, Е.П. Мирошникова, М.С. Мирошникова, В.А. Антипов \\ Оренбургский государственный университет, 460018, г. Оренбург, пр. Победы 13 \\ *e-mail: ifkarimov@yandex.ru
}

РЕЗЮМЕ. В последние десятилетия актуально изучение наночастиц металлов и попытки их применения в различных сферах деятельности человека. В области микробиологии часто подобные агенты используются в качестве биоцидных факторов, способствующих элиминации нежелательной микрофлоры. Данная работа посвящена оценке действия кормовых добавок на основе наночастиц железа и меди с добавлением коры дуба или пробиотических препаратов на изменение чувствительности кишечной микрофлоры цыплят-бройлеров к антибиотикам. Показано, что наночастицы металлов способны повышать количество устойчивых к антибиотикам форм бактерий, что потенциально создает генетический резерв, который в дальнейшем может быть использован неблагоприятной микрофлорой.

КЛЮЧЕВЫЕ СЛОВА: наночастицЫ, антибиотики, микрофлора, кормовая добавка.

\section{ANTIBIOTIC RESISTANCE PROFILE OF BROILER CHICKENS INTESTINAL MICROFLORA WHEN USING METAL NANOPARTICLES IN FEEDING}

\section{I.F. Karimov, E.P. Miroshnikova, M.S. Miroshnikova, V.A. Antipov}

Orenburg State University, Russia, 460018, Orenburg, Pobedy av., 13

*e-mail: ifkarimov@yandex.ru

ABSTRACT. In recent decades, metal nanoparticles have been studied and attempts have been made to use them in various fields of human activity. In the field of microbiology, such agents are often used as biocidal factors that contribute to the elimination of unwanted microflora. This work is devoted to assessing the effect of feed additives based on iron and copper nanoparticles with the addition of oak bark or probiotic preparations on the change in the sensitivity of the intestinal microflora of broilers to antibiotics. It has been shown that metal nanoparticles can lead to an increase in the number of antibioticresistant forms of bacteria, which potentially creates a genetic reserve that can be further used by unfavorable microflora.

KEYWORDS: nanoparticles, antibiotics, microflora, feed additive.

\section{ВВЕДЕНИЕ}

В настоящий момент одним из популярных направлений развития в сельском хозяйстве является применение кормовых добавок с целью сбалансирования профиля питательных веществ рациона (Dwyer, et al., 2015). Один из вариантов кормовой модификации - использование наноразмерных материалов, что включает в себя наноразмерные порошки для увеличения поглощения питательных веществ; нанокапсулирование нутрицевтиков для лучшего поглощения, повышения стабильности или целевой доставки необходимых компонентов; нанохелаты для более эффективной доставки питательных веществ (Akhavan, et al., 2018). При использовании нанотехнологий безопасность является главной проблемой и должна быть рассмотрена в первую очередь.

Цель работы - изучение действия добавок на основе ультрадисперсных частиц металлов, а также отвара коры дуба и пробиотиков на антибиотикочувствительность бактерий кишечника цыплятбройлеров.

\section{МАТЕРИАЛЫ И МЕТОДЫ}

В работе использованы цыплята-бройлеры кросса «Arbor Acres Plus» в возрасте от 7-35 дневного возраста. Для эксперимента отобраны 90 голов недельных цыплят-бройлеров, которые методом аналогов разделены на 12 групп $(n=7)$. По истечению подготовительного периода (7-14 суток) птица переведена на условия основного учетного периода (15-35 суток). В качестве модифицирующих 
добавок использованы ультрадисперсные препараты производства ООО «Платина» (Москва, Россия):

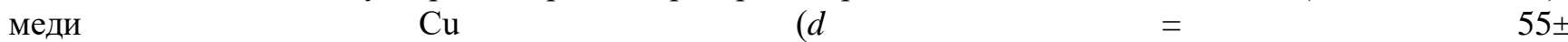
\pm 15 нм; Z-потенциал $\left.31 \pm 0,1 \mathrm{mB} ; \mathrm{S}_{\text {пов }}=9 \mathrm{~m}^{2} / \Gamma\right)$ в дозировке 1,7 мг/кг и железа Fе в дозировке 17 мг/кг; про-биотический препарат на основе культуры клеток Bifidobacterium longum в составе препарата «Соябифидум» (ООО «НПФ «Экобиос», Оренбург, Россия) с содержанием не менее 109 клеток, в дозировке 0,7 мл/кг корма; отвар коры дуба (Quercus cortex) в дозировке 2 мг/кг корма.

\section{РЕЗУЛЬТАТЫ И ОБСУЖДЕНИЕ}

Для фторхинолоновых антибиотиков выявлено понижение чувствительности бактериальных штаммов, полученных от птиц, в рационе которых дополнительно присутствовали наночастицы металлов в комбинации с другими добавками, по сравнению с контрольной группой. Наличие пробиотического штамма не вело к значительному изменению чувствительности бактерий к антимикробным препаратам, однако их сочетание с наночастицами (особенно железа) привело к резкому возрастанию устойчивых форм. Применение в качестве кормовой добавки отвара коры дуба, самостоятельно не проявляющей выраженной активности на изменения профиля антибиотикочувствительности исследуемых культур, в сочетании с пробиотическим штаммом привело к росту штаммов, устойчивых к ампициллину и ципрофлоксацину, а привнесение наночастиц металлов еще больше усилило данный эффект.

\section{ВЫВОДЫ}

Результаты исследования демонстрируют, что использование кормовых добавок, в первую очередь на основе наночастиц металлов, а также их комбинаций с другими препаратами, способно в значительной степени повлиять на особенности микробиоты кишечника животных и птиц, привести к изменению их физиологической активности и адаптационных возможностей, что потенциально может отразиться на состоянии макроорганизма.

\section{Список литературы / References}

1. Akhavan S., Assadpour E., Katouzian I., Jafari S.M. Lipid nano scale cargos for the protection and delivery of food bioactive ingredients and nutraceuticals. Trends in Food Science \& Technology. 2018; 74: 132-146.

2. Dwyer J.T., Wiemer K.L., Dary O., Keen C.L., King J.C., Miller K.B., Philbert M.A., Tarasuk V., Taylor C.L., Gaine P.C., Jarvis A.B., Bailey R.L. Fortification and health: challenges and opportunities. Adv. Nutr. 2015; 6(1): 124-131. 